\title{
Against the Odds: Why Some Children Fare Well in the Face of Adversity
}

\author{
GINA CRIVELLO ${ }^{1}$ AND VIRGINIA MORROW \\ Department of International Development, University of Oxford, Oxford, United Kingdom
}

\begin{abstract}
This article asks why some children growing up in poverty seem to fare well, despite the odds being stacked against them early in life. The data come from Young Lives, a 15-year mixed methods study of childhood poverty tracing the trajectories of a cohort of boys and girls $(n=4,000)$ born in 1994 in Ethiopia, India, Peru and Vietnam. We use survey data to identify children in the poorest households who, by age 22, were faring well. The article addresses three main questions: (a) What are the key determining moments in children's lives? (b) What makes a difference for children during these turning points? And (c) what made a difference in the lives of those children who have fared well despite facing adversity? The findings demonstrate the crucial role of children's social relationships and support networks, migration, institutional barriers, the importance of hope and 'second chances'. However, a longitudinal approach illuminates the ongoing nature of human vulnerability and the fragility of young people's life trajectories in contexts of poverty.
\end{abstract}

Keywords: children; youth; poverty; inequality; wellbeing; life course

\section{Introduction: growing up with the Millennium Development Goals}

This article asks why some children who grow up in poverty are seemingly 'beating the odds' despite facing severe disadvantage. It explores how young people navigate their life trajectories and the protective factors that matter for those who experience challenging circumstances from a young age (Munford and Sanders 2019). There are nearly 1.8 billion young people aged 10 to 24, the largest youth cohort ever recorded in history. Eighty-nine per cent (9 out of 10) live in less developed countries (UNFPA, 2014). [1] This generation has grown up under an ambitious set of 'globalising solutions' formulated to address the world's development problems (Jones and Chant, 2009), embodied by the Millennium Development Goals (MDGS, 2000-2015), and currently, the Sustainable Development Goals (SDGs, 2015-2030). Reducing global poverty, expanding school enrolment and improving access to clean water and sanitation promise transformation in children's lives. The SDGs go further than the MDGs in their explicit aim to tackle inequality by reaching the most marginalised, pledging that no one will be 'left behind'.

The data for this article come from Young Lives, a longitudinal study of childhood poverty in Ethiopia, India, Peru and Vietnam. [2] Young Lives was designed to explore the effect on children of

\footnotetext{
${ }^{1}$ Corresponding Author: gina.crivello@qeh.ox.ac.uk
} 
the MDGs, and over-sampled for resource-poor communities and households. Overall, the study has found that despite economic hardship, and in many cases, because of it, school education represented hope for breaking intergenerational cycles of poverty. Families' aspirations were high, their collective futures resting tenuously on the shoulders of the young, many of whom went on to study further than any of their family members had before them. They adjusted their expectations when circumstances changed, and by age 22, the trajectories of the young participants had diverged. Many had left school before they wanted to. They were earning money to meet their evolving family responsibilities. Some stayed close to home; for others, migration promised a pathway to better opportunities. More girls than boys had married and had given birth to their first children. The timing of these changes varied between individuals, influenced by a combination of social expectations reflecting gender, age and family norms, differing opportunities and experiences of poverty (Boyden et al, 2019). Arguably, many were 'left behind' and at risk of feeling like 'failures', subject over time to what Berlant (2006) has termed a 'cruel optimism' when the hope for a good life and a better future diminishes. Documenting their diverse pathways means we can identify children who appear to be doing well in their early twenties, and this paper explores why. These are the individuals who might be labelled as 'resilient' or as examples of 'success'. Research literature is full of metaphors; they are 'flourishing under fire' (Ryff and Singer, 2003), 'escaping disadvantage' (Pilling, 1990), 'overcoming the odds' (Werner and Smith, 1982), 'making it' (Masten et al, 2004), 'bucking the trend' (Blanden, 2006); they have a 'talent for life' (Scheper-Hughes, 2008) and can 'bounce back' after difficult periods (Smith et al, 2008).

But does 'resilience' look the same everywhere? What does 'making it' look like for the daughter of indigenous farmers in a Peruvian village? What can be counted as later 'success' for a boy orphaned early in life in Ethiopia's capital city? Is leaving school before graduation or marrying as a teenager necessarily a sign of 'failure'? Surely, contextual disparities in opportunities, such as job markets or good schools, must inform our understandings of positive 'outcomes'. An outcome deemed a failure by one definition might be an indicator of success by another. Provocations like these led us to develop the following research questions: a) What are the determining moments in children's lives?; b) What makes a difference for children during these turning points?; and c) What made a difference in the lives of those children who have fared well despite facing poverty and adversity?

We structure the article as follows. The next section summarises existing literature, then we describe Young Lives and our analytical approach. The remainder is organised around a set of themes and illustrative life stories from a selection of boys and girls we judged to be doing well 'against the 
odds' and the differing factors that helped them. Finally, we reflect on challenges encountered in attempting this type of analysis, and offer implications for policy.

\section{Theorising young people and their contexts}

\section{Crucial moments and life trajectories}

Growing up in a challenging environment does not automatically deliver young people a bleak life sentence; marginalised youth strive to lead lives that they have reason to value (Sen, 2000). However, their paths to respectable adulthoods can be 'complicated and convoluted journeys' (Langevang, 2008), and variation in pathways has implications for the emergence of inequalities in childhood (Dornan and Woodhead, 2005: 9). The notion of 'transitions' is problematic because it assumes that young people's trajectories are predictable, uniformly linear and sequential, but the reality is different (Juarez et al, 2014; Morrow, 2013; Ursin and Abebe, 2017). Johnson-Hanks (2002) proposed the notion of 'vital conjunctures' to emphasise the coming together of processes and circumstances to shift trajectories. Applied here, vital conjunctures are the 'turning points' in young people's biographies, 'specific periods of potential transformation in a life or lives' that have the potential to trigger instability and/or hope (Johnson-Hanks, 2002: 870). Of chief interest are young people's strategies for navigating these critical junctures across time and space (Jeffrey, 2010: 498).

\section{Youth uncertainty}

What is the contemporary context shaping the vital conjunctures for young people? Recent studies of youth in low- and middle-income countries paint an unpromising picture characterised by 'uncertainty', 'crisis' and 'failure'. One discursive finger points to the failures of development (Jones and Chant, 2009) and the context-driven uncertainties that limit young people's prospects which are thought to be worse compared to past generations who, unlike the current generation of youth, could count on formal education leading to formal employment as a route to security (Jeffrey and McDowell, 2004; Langevang, 2008; Locke and Lloyd-Sherlock, 2011). Heightened educational aspirations married with greater educational attainment have met the realities of a shrinking or nonexistent youth labour market; this, at a moment in the gendered life course when social expectations on individuals to attain adult status intensify. In this view, the 'maps of life' are 'eroding' for youth (Jeffrey 2010), meanwhile some young people experience 'crisis' as the norm in their localities, a constant, everyday reality, rather than a temporary anomaly (Vigh, 2006).

The other discursive finger points to the kinds of individual subjectivities produced by uncertain contexts (Cooper and Pratten, 2015), to cruel optimism (Berlant, 2006) and to the risk of individual 'failure' (Morrow, 2013). There is increasing concern that 'education is not helping the 
poor' and about what happens to educated children who become under- or un-employed youth (Datzberger, 2018; Jeffrey et al, 2008). Many rural youth no longer want to be farmers (Boyden, 2013; Crivello, 2015; White, 2011) whilst the image of urban youth as self-motivated, aspiring entrepreneurs is also showing its limits (Gough and Langevang, 2016). Given this, our aim is to say something potentially useful about child wellbeing and vulnerability, in what has recently been referred to as the move away from 'narratives of failure' towards 'narratives of possibility' (Gilligan, 2015). With regard to human development, this calls for less attention on youth risk-taking behaviours, and greater attention to young people's logics and strengths and to the contexts that constrain or bolster them (Lerner, 2008; Lippman et al, 2009).

\section{'Resilience'}

Some scholars reject the notion of 'resilience' altogether on the basis that it promotes a kind of neoliberal agency through which individuals are expected to overcome vulnerability (Bracke, 2016; Neocleous, 2013). Other scholars continue to work within the field of 'resilience' but advocate for more critical and nuanced approaches, for example, that place greater emphasis on context and cultural variability rather than searching for universals; view resilience as a process and as a product of social relationships rather than as a psychological attribute of individuals; value qualitative and person-centred approaches, and; see resilience as pertaining to ordinary (rather than extraordinary, 'invulnerable') people (cf. Masten, 2001; Ungar, 2004).

Definitions and the impacts of risk vary, and not everyone who experiences the same circumstances will feel that they were deprived (Boyden and Cooper, 2007; Tekola, 2009; Pilling, 1990). Some studies have found that exposure to adversity does not necessarily cause harm or deepen vulnerability (Boyden and Mann, 2005; Rutter, 1990). An individual may demonstrate 'resilience' in one sphere (e.g. educational success) but struggle in other aspects (e.g. emotional wellbeing) (Camfield, 2012; Luthar, 1991). Gilligan's broad definition of resilience as 'about people doing better than expected in unpromising circumstances' is appealing; however, the question of what might be 'expected' is not straightforward, as we show below.

Longitudinal approaches are ideal for investigating what helps children overcome earlier disadvantage, although most studies have been undertaken in wealthier industrialised countries (MacLeod, 2009; Pilling, 1990). In Hawaii, the Kauai Longitudinal Study followed 505 children born into disadvantage in the mid-1950s into their thirties, and found that having caring adults outside the family on whom children could rely for support was a significant protective factor, their relative influence varying at differing ages (Werner and Smith, 1992: 178). 
There are few longitudinal investigations in lower- and middle-income countries, but some notable ethnographic studies stand out. Perlman's (2010:10) research (1968-2008) over four generations in urban shantytowns in Brazil identified the ten most successful and ten least successful individuals in her sample, finding that 'location, networks, family values and individual differences, along with just plain luck, had a lot to do with upward or downward mobility'. Anderson's (2007) 30-year study followed 56 families in poor neighbourhoods in Lima, Peru, examining poverty dynamics and intergenerational change. Anderson (2007:238) critiqued the notion of 'intergenerational transmission of poverty' on the grounds that such an idea locates responsibility and agency in persons and generations and thereby 'distract us from analyses of the structural and contingent forces that continuously create new forms of poverty.'

\section{Methodology}

\section{Young Lives}

Young Lives is a fifteen-year, international cohort study that aimed to shed light on the drivers and impacts of childhood poverty. Since 2002, the study has collected five rounds of child, household and community survey data linked to 4,000 children born in 1994 in the four study countries. [3]

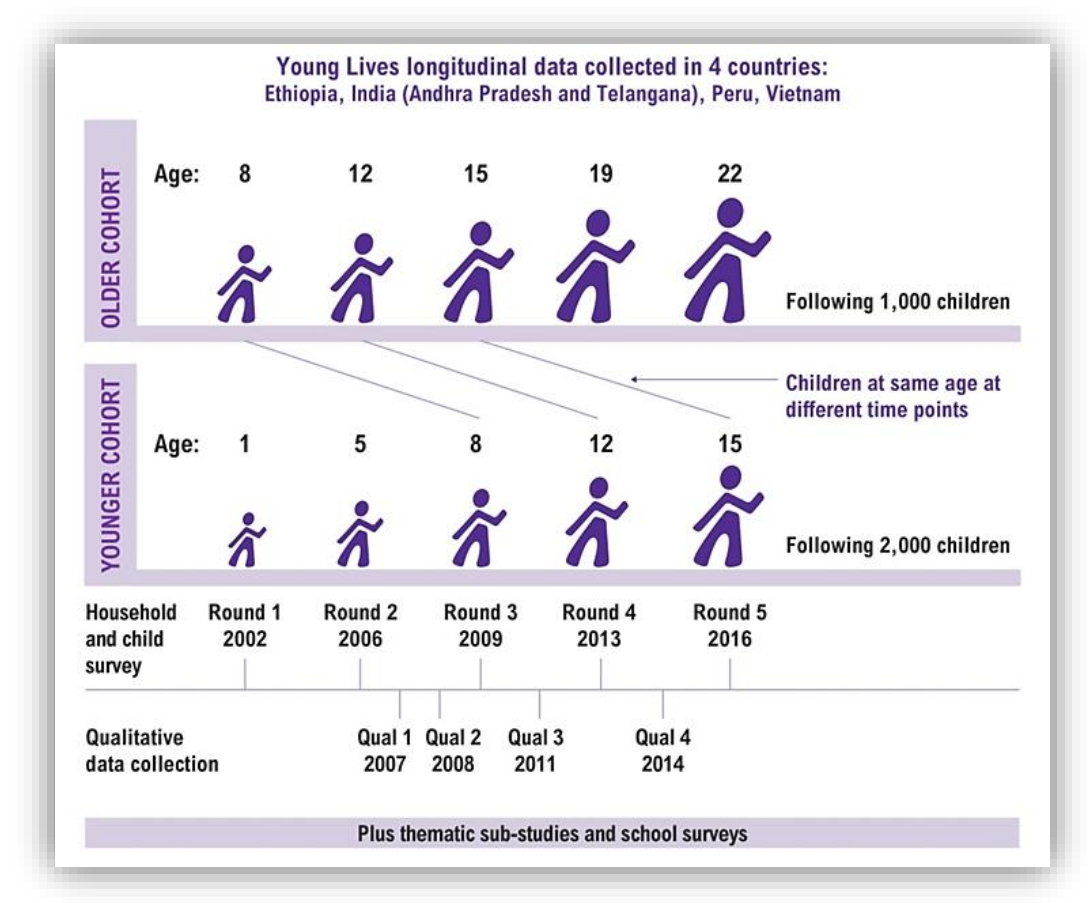

Additionally, a nested sample of over 100 children participated in qualitative longitudinal research, exploring everyday experiences of poverty and wellbeing between 2007 and 2014, from around age 12 to 19 (Crivello et al, 2013). Biographical interviews, including life histories, and group discussions across four time points engaged children, parents/caregivers and community members. The study 
design allows us to see commonalities and differences across countries using similar instruments; the emphasis here is on what the children who 'fared well' had in common.

\section{Selection of cases}

The approach for selecting exemplary cases was intentionally iterative and flexible, opting for a combination of etic and emic criteria, starting with the larger data set, with each phase going deeper and narrower, as follows.

- Agreed a list of indicators for the whole cohort of young people at age 19 (Round 4 Survey), including cognitive and socio-emotional scores, marriage and work status and subjective wealth. [4]

- Identified 'the averages' by gender, location, and wealth status.

- Mapped survey outcomes for individuals in the qualitative sample to determine where each child was located in relation to the mean across the indicators.

- Began iterative selection process, starting with the children in the poorest households (Wealth Tercile 1), [5] reviewing their outcomes to identify which children appeared to be faring better than others - noting patterns of gender, wealth and location.

- Reviewed the qualitative data, including information gleaned from life course timelines in which children had identified 'good' and 'bad' moments in their lives to explore the nature and timing of adversity, risks and shocks.

- Shortlisted six children per country, creating a set of longitudinal profiles for each child based on qualitative and survey data.

- Assessed the outcomes for the young people at age 22 in 2016 (Round 5 survey, which had become available), again checking enrolment, marital and employment status and satisfaction with life, finally settling on a core list of eight children: one boy and one girl per country [See Table 1].

We biased our selection process towards children from the poorest households who had experienced many difficulties, yet appeared to be doing well. The eight core cases therefore may not objectively be the 'most successful'. A poor child still enrolled in school at age 19 was probably a fair indication of resilience, but we also considered grade progression and what was typical for a child's locality. Moreover, poverty status was skewed towards rurality. For rural boys, resilience may be indicated by 'hanging on' in the school system, rather than above average progress. 
Table 1. Background characteristics of children selected as exemplars of positive life trajectories

\begin{tabular}{|c|c|c|c|c|c|c|c|c|c|}
\hline NAME & Country & Sex & $\begin{array}{l}\text { Wealth Tercile } \\
(1=\quad \text { poorest; } \\
3=\text { less-poor })\end{array}$ & $\begin{array}{l}\text { Location } \\
\text { origin }\end{array}$ & $\begin{array}{l}\text { Sibling birth } \\
\text { order }\end{array}$ & Main activity & $\begin{array}{l}\text { Highest level } \\
\text { education age } 22\end{array}$ & $\begin{array}{l}\text { Highest level education } \\
\text { caregiver (2013) }\end{array}$ & $\begin{array}{l}\text { Illustrative quote from child } \\
\text { reflecting child's trajectory }\end{array}$ \\
\hline MULU & Ethiopia & Female & 1 & rural & 5 of 7 & Studying & $\begin{array}{l}\text { Enrolled in } \\
\text { University }\end{array}$ & $\begin{array}{l}\text { Mother: Adult literacy course } \\
\text { Father: --- }\end{array}$ & $\begin{array}{l}\text { 'My life will be better than my } \\
\text { mother's because I am educated' }\end{array}$ \\
\hline MESIH & Ethiopia & Male & 1 & rural & 4 of 5 & Studying & Enrolled in Grade 12 & $\begin{array}{l}\text { Mother: None } \\
\text { Father: Religious education }\end{array}$ & $\begin{array}{l}\text { 'The challenges helped me } \\
\text { become stronger' }\end{array}$ \\
\hline SARADA & India & Female & 1 & rural & 1 of 3 & $\begin{array}{l}\text { Teaching } \\
\text { (working) }\end{array}$ & $\begin{array}{l}\text { Some University } \\
\text { (left in 2015) }\end{array}$ & $\begin{array}{l}\text { Mother: None } \\
\text { Father: None }\end{array}$ & 'I am not afraid of problems' \\
\hline RAJESH & India & Male & 1 & rural & 4 of 4 & $\begin{array}{l}\text { Studying } \\
\text { (returned after } \\
\text { leaving school) }\end{array}$ & $\begin{array}{l}\text { Enrolled in } \\
\text { Vocational }\end{array}$ & $\begin{array}{l}\text { Mother: None } \\
\text { Father: Grade } 5\end{array}$ & $\begin{array}{l}\text { 'My sisters are taking care of me } \\
\text { so that I may prosper' }\end{array}$ \\
\hline MARIA & Peru & Female & 1 & rural & 1 of 3 & Studying & $\begin{array}{l}\text { Enrolled in Nursing } \\
\text { programme }\end{array}$ & $\begin{array}{l}\text { Mother: Grade } 8 \\
\text { Father: Grade } 6\end{array}$ & $\begin{array}{l}\text { 'Having my own money means } \\
\text { not depending on a man' }\end{array}$ \\
\hline ELMER & Peru & Male & 1 & rural & 3 of 4 & $\begin{array}{l}\text { Studying and } \\
\text { working (petrol } \\
\text { station) }\end{array}$ & $\begin{array}{l}\text { Enrolled in Institute } \\
\text { of Higher Education } \\
\text { (mechanical } \\
\text { engineering) }\end{array}$ & $\begin{array}{l}\text { Mother: Grade } 1 \\
\text { Father: Grade } 3\end{array}$ & $\begin{array}{l}\text { 'I've grown bigger, I have a } \\
\text { moustache and goals' }\end{array}$ \\
\hline LIEN & Vietnam & Female & 2 & rural & 2 of 3 & Studying & $\begin{array}{l}\text { Enrolled in } \\
\text { University } \\
\text { (Social Work) }\end{array}$ & $\begin{array}{l}\text { Mother: Grade } 9 \\
\text { Father: Grade } 9\end{array}$ & $\begin{array}{l}\text { 'My sister sets a good example for } \\
\text { me to follow' }\end{array}$ \\
\hline QUOC & Vietnam & Male & 2 & rural & 2 of 3 & Working & $\begin{array}{l}\text { Left } \\
\text { Grade } 9\end{array}$ & $\begin{array}{l}\text { Mother: None } \\
\text { Father: None }\end{array}$ & $\begin{array}{l}\text { 'I will make enough money so my } \\
\text { parents won't have to work } \\
\text { anymore' }\end{array}$ \\
\hline
\end{tabular}




\section{Analytic approach}

We undertook thematic analysis using four rounds of qualitative data (age 12-19), combining within-case analysis (of individual biographies) and cross-case analysis (identifying wider structural factors, similarities and differences). Longitudinal biographies for each child identified what made a difference, when and why, building a cumulative picture of the ecologies of support for children in different contexts (Bronfenbrenner, 1979; Ungar, 2011). Emergent themes were as follows: relationships support from family, other kin and friends; enabling systems and environments, from NGO and government social protection; the importance of being given a second chance; and, individual resources (personal characteristics, positive dispositions and competencies). Finally, we explored a case where a young man appeared satisfied with life according to his own criteria, this leading us to question the values behind the premise of 'succeeding against the odds'.

We situated the qualitative cases within the context of cohort trends in the survey, and to better understand possible gendered dimensions of 'resilience' (Bracke, 2016: 65). By age 19, girls were more likely compared to boys to still be enrolled in school in Ethiopia, Peru and Vietnam, but not in India. [6] Boys were more likely compared to girls to be working full-time in all countries (eg. Ethiopia $36.3 \% \mathrm{v} 18.6 \%$; Vietnam $44.5 \% \mathrm{v}$ $25.6 \%$ ). Girls were more likely to be married or cohabiting (eg. India $37 \%$ v $2 \%$; Peru $19.7 \%$ v $6.7 \%)$.

'Resilience' was a heuristic device rather than a structured/quantitative measurement tool. The process of selecting cases exposed difficulties in identifying 'ideal' cases, since individuals may have done well in one domain but not in another. The individual case approach was useful in this regard because it illuminated complexity and the wider social processes and structures in which lives take shape (Jeffrey and Dyson, 2008; Locke and Lloyd-Sherlock, 2011; Ragin and Becker, 1992). The qualitative approach emphasised children's narratives, their explanations of path dependency and the role of agency and constraints in constructing individual trajectories.

\section{Children and young people navigating change}

We start by reporting on findings from the full qualitative sample before focusing in on the core cases. Overall, children and young people reported navigating a multitude of intersecting changes, notably: (i) climatic shocks (drought, rains, pests); (ii) school structures (exams, teacher relationships); (iii) household changes (death, illness, divorce, 
job or asset loss, sibling marriage); and (iv) child health and development. Changes could be gradual or abrupt, planned for or unexpected, occur in differing combinations, with varied impacts on children's trajectories.

\section{Children's reports of changes}

Children's life-course timelines depicted important events at different ages. Early years showed children as dependents and recipients of adult care and resources, and loss of parental support created difficulties for them. A gradual shift occurred as children grew older and assumed roles as providers of care and support for others in the home (e.g. paying off family debts). Adolescence was a time of growing responsibility and of increased gender-differentiation; the period between the ages of 14 and 17 saw reports of independent migration, self-initiated income earning activities, marriage and childbirth. Girls emphasised increased household work, and boys paid work, with some variation by location. For example, livestock featured consistently in rural Ethiopian boys' narratives of 'good' and 'bad' memories reflecting boys' roles in herding; boys attributed the acquisition, loss, sale, injury from or theft of cattle, goats etc. as determinants of their wellbeing and of their standing within the household.

Children narrated their personal histories largely through the changing experience of household and family. Their immediate and proximal household environments stood out as primary sources of both risk and protection, as did the quality of their family relationships, as these changed over time through births, deaths, separations, migration and so on. Ongoing poverty was a backdrop of everyday life for many, creating pressures on families, especially when combined with family discord and violence or family illness, which were experiences that cut across all phases of childhood (Pells and Morrow, 2018). Lack of safety nets weakened families' capacities to deal with unanticipated difficulties which frequently led to school interruptions or increased responsibilities in work, economic decline and diminished hope (Tafere, 2014).

\section{'Turning points'}

Turning points frequently involved crucial decision-making with respect to young people's futures, yet young people's involvement in decision-making was not a given. Not all reported changes were equal, some were experienced as risks, others as protective or simply as what was 'normal' or expected. Under pressurised conditions of poverty and compounding disadvantage, turning points could be experienced as tipping life 
chances and fortunes in transformative (positive or negative) directions. Examples included parental death, marriage for girls and migration, the consequences of which depended on contexts/circumstances. Sometimes the influence of gender norms on decision-making was stark, but gender processes operated alongside factors of poverty, age, location and physical dis/ability in structuring the odds for children. The remainder of the paper examines the factors that helped girls and boys.

\section{What helped?}

Overcoming the odds seemed to require a combination of timely, mutually reinforcing factors, rather than one single factor. Four clusters of factors emerged in the analysis of children's life histories: (i) supportive relationships from within and outside the family; (ii) government and NGO support; (iii) enabling systems and environments; and (iv) children's individual resources.

\section{Supportive relationships: family, teachers and other facilitators}

Many families lacked formal support and safety nets, consequently, children relied on their social relationships to manage change and to get ahead in the longer term. All children discussed here had counted on one or more individuals for critical support at difficult times; instrumental to children's trajectories were parents and caregivers, elder siblings, wider kin and teachers. The positive influence of friends grew over time. Most parents were unable to provide adequate financial support to their children, and rural parents often lacked the cultural capital to advise children about higher education and professional careers. Children who fared well were able to count on parents' practical support to attend school, including through the assignment of responsibilities at home and in work that were manageable alongside schooling. They tapped into a wider web of support beyond their parents: cousins, aunts, uncles and grandparents provided information about and access to schooling, jobs, housing and migration. Aunts and uncles were role models. Elder sisters in particular were influential in children's webs of support, and both older sisters and brothers were examples of possible and desirable futures, as well as cautionary examples of what to do differently. As elder siblings advanced through schooling systems, left home, obtained jobs, and started families, their roles as advisors, fixers, financial supporters and migration facilitators grew in importance.

MULU (case 1) grew up in a poor household in a rural community in Amhara region, Ethiopia, the fifth of seven siblings. Her family experienced economic decline 
following the death of her father when she was nine. They received aid because of their situation. Age ten, she started picking coffee, and later, haricot beans for cash, with her sisters, and she attended school. Her mother's illness resulted in more housework for the children. Although she found it difficult to manage school, housework and paid work, Mulu reasoned that the money she earned helped her household and paid for schooling. Mulu's elder sister joined college when Mulu was thirteen; four years later, her sister got a job and moved to town. Her sister sent money home, but her leaving meant more housework for Mulu. Conflict arose with her younger sister who pressured Mulu to earn more money haricot picking and spend less time on schoolwork. Passing the national Grade 10 exam strengthened Mulu's resolve to continue studying. Her elder sister lobbied their mother to allow Mulu to move to town with her to study. Age twenty-two, Mulu was living with her elder sister, in town, in her third year of university. 


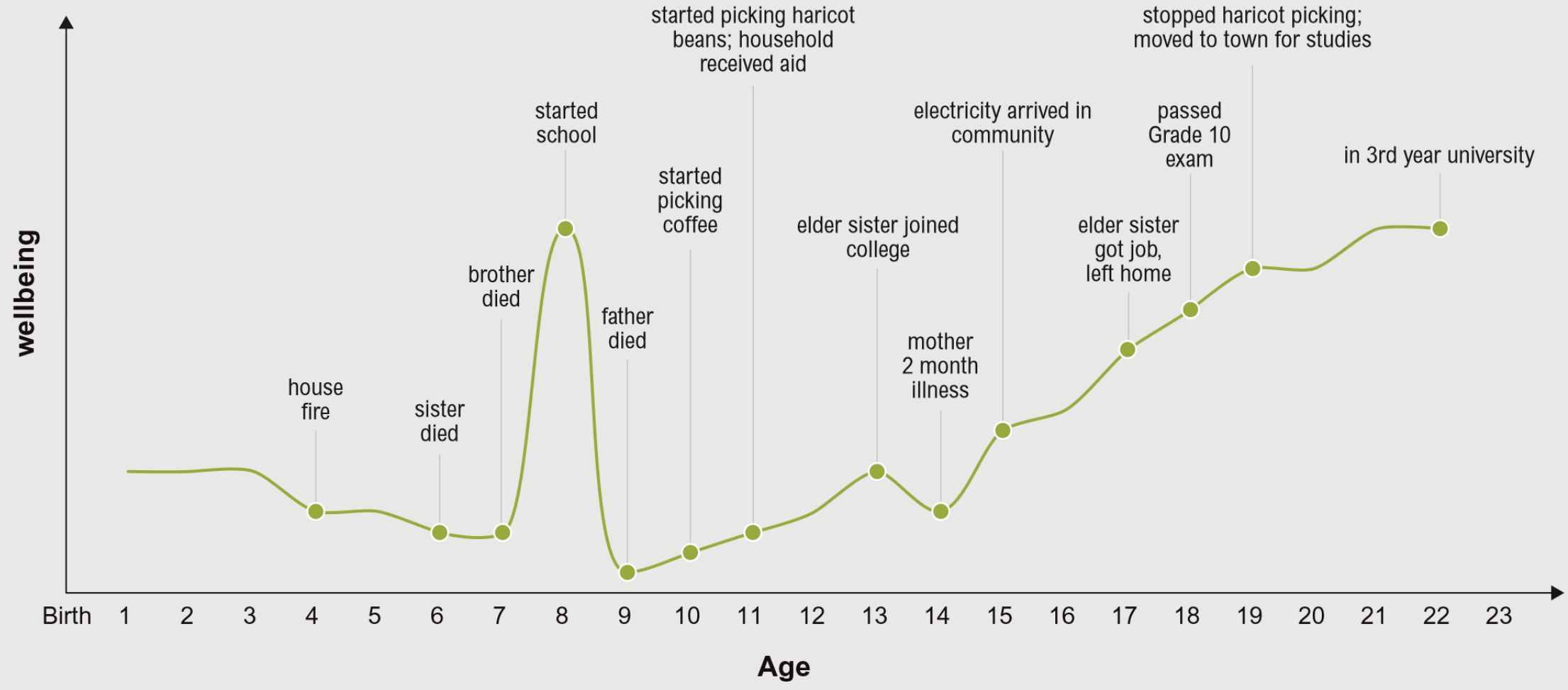

Mulu, born 1994, Amhara region, Ethiopia.

(Source: Life Course Timeline Exercise, Repeat Biographical Interviews, Round 5 Survey) 
MARIA (case 9) grew up in a village in the jungle region of Peru, the eldest of three girls. Her father drove a moto-taxi and her mother sold beauty products. Her parents' marriage was rocky, and her mother impressed on her daughters the importance of attaining financial independence to avoid relying on men. Maria and her sister earned money as farm hands and by washing dishes at the market. When she was 12, Maria moved to her grandparents in town where the secondary school was better. She returned after a year due to homesickness. Having finished secondary school, aged 17, she moved to the city to attend Beautician School and she worked as a live-in cleaner to support herself. Finding it too difficult to work and study, she returned home, fearful she might not have another chance at learning. Age 19, Maria's aunt persuaded her to join a threeyear nursing programme with her, despite Maria's father's objections. Maria's aunt lobbied on Maria's behalf and convinced the father to let Maria move in with her and her husband. Age 20, still missing her family, Maria was progressing in her nursing programme, well-supported by her aunt's family.

Rural children wishing to study beyond primary school were often left with little choice but to migrate, lest they endure lengthy, potentially unsafe or costly daily commutes. Families worried about girls in particular who, compared to boys, they deemed in greater need of surveillance. Girls like Mulu and Maria benefited from the guarantee provided by trusted relatives to keep a watchful eye over them.

Boys also relied on relatives to move, especially when they were younger. ELMER (case 6) grew up in a poor household near Maria's village, and mobility was crucial to the shaping of his trajectory, as part of a wider family strategy. When Elmer was 12 his elder sister sent for him to join her in Lima (the capital) so that he could look after her children while she and her husband worked. In exchange, she paid for his upkeep and schooling. The previous year, Elmer's older brother (17 years old) lived with her for the same reason but he had since returned to his village to graduate. After one year, the brothers swapped places again; Elmer returned to the village. Meanwhile, Elmer's parents moved to a different village (to farm) where schooling was not available so Elmer and his younger siblings rented a place near a school, and on weekends, they worked on their parents' farm. Age 17, Elmer enrolled on a business course on advice from a friend who said choosing that career would mean not 'having to get your hands dirty', unlike the agricultural farm work they both grew up doing. By age 18, Elmer's family had relocated to Lima where Elmer was studying mechanical engineering at college and working the night shift at a petrol station. 
In other cases, it was the support from individual teachers who championed children's interests that made a decisive positive difference. Teachers helped children navigate tipping points, such as when they failed key exams, or when they missed classes on account of being needed at home to care for sick family members. Teachers could be 'make or break' for children, since inter-personal conflict with teachers derailed the schooling trajectories of several children in the qualitative study. When combined with inflexible schooling systems, children found it difficult to return to school.

In Vietnam, teachers helped LIEN (case 7) and QUOC (case 8) overcome difficult turning points. They both grew up in Van Tri, a prosperous rural area in the Red River Delta. Lien's childhood was marred by her parents' relationship - her father was frequently absent, did not contribute much, and had been violent towards Lien's mother. The family was very poor, and Lien worked stitching bags at home outside school hours - she spoke proudly of being able to earn money (she lent the money to her sister for university fees), but understood that she needed education and that working interfered with her studies. Lien was proud of her older sister who had earned the family's respect when she passed her university entrance exam - the first person in the family to go to university. 'She sets a good example for me to follow'. Lien encountered a 'tipping point', age 15, when she failed her high school entrance exam, which she sat the day her grandmother died. She was devastated. Her uncle threatened that if she was unable to learn she would have to remain home. She repeated Grade 9 for one term, continuing sewing bags, then turned her attention to preparing to re-sit the exam. She took the initiative to write to her school's vice principal:

I wrote the request letter on my own, with the help of a relative living nearby... I asked [the vice principal] to help me register for the school's additional courses. He told me to make a request. I followed all of his instruction. He introduced me to a teacher and asked for her permission for me to study in her class. She accepted and I started studying there.

By aged 22, Lien was studying social work at a university in Hanoi.

Quoc's case is different because at age 22, he had a girlfriend, a baby and was working. He did well in primary school but his grades declined in secondary school. His family struggled against severe poverty so working consumed most of their time and attention (Zharkevich, 2016:22). As a teenager, Quoc was addicted to video-gaming and was struggling. His uncle took him into his home and enrolled him in a different school after he became embroiled in a school conflict. Aware of Quoc's history, his new teacher 
(Mrs T) provided additional support to him. In Quoc's depiction, she 'adopted' him as a son, and he was happy to have 'one more mother'. Despite her support, he failed the Grade 9 exam; rather than re-taking it, he used his girlfriend's networks to secure a factory job. Looking back, he believed he 'stood on his own' and 'did not need help from anyone.' Support from his uncle and Mrs T helped him through difficult periods but these relationships were not enough to see him through to complete his schooling. Age 22, with new priorities, he said, 'I am still very optimistic.'

\section{NGO and government support}

Local, community-based NGOs and Self-Help Groups were vital sources of support for some children with specific vulnerabilities, such as a disability. A case from India illustrates this. SARADA (case 3) lived in a village (Poompuhar), and had been very ambitious throughout her childhood. She had a physical disability that meant she could only walk short distances, and found it difficult to stand for any length of time. Her family belonged to a low-caste community (BC) and took out a loan to build a new house when their old house collapsed. Sarada and her younger siblings were taken out of school to work to pay off the debt. However, against her parents' will, Sarada insisted on going to school, and the local self-help group, the Disabled People's Association, provided her with financial support (a free bus pass, and $200 \mathrm{Rs} /-$ a month), enabling her to continue into secondary school. However, this involved a bus journey, which was physically difficult. Aged 16, she was working weekends to pay for a taxi to take her to college. Aged 20, Sarada was two years into her degree. The family financial situation had improved (though her younger siblings were still debt-bonded). Sarada was teaching parttime in a night school and wanted to become a professionally qualified teacher. The selfhelp group had not only directly supported her, it also provided a source of informal support when she was being harassed by a boy, and could not turn to her family for help:

He called again in the night ... all of us were eating dinner. I kept the phone on silent mode. ...Then I got scared that my parents would scold me. There is one lady who taught me tailoring in the summer... I call her Akka (sister). I went to her and told her what has happened. She is also a handicapped lady. ... She called back that boy and scolded him and said that I am her sister ... he said he just talked to me for time pass [to pass the time]. She also said that my marriage had been

fixed and not to call me anymore. ... Akka told me the consequences of such incidents ... people would think that I have some kind of relationship with him, 
and I should not be doing such things.... Akka scolded him saying that he is not from our caste and not our relative, why is he harassing us like that? This went on for one month. After that, he stopped calling. ... I did not tell anyone except Akka and she solved the problem...

By age 20, Sarada was leader of her local self-help group, she had learned banking skills, and was helping other people with disabilities to access benefits. Sarada's involvement with the Disabled People's Association gave her confidence to challenge her parents' authority when they wanted her to work instead of going to school. Her educational experience in turn meant that she was identified as a respectable person, and as a leader, emboldening her to challenge strict gender norms.

Many children (including those who did not fare as well) mentioned their household's participation in social protection programmes (e.g., PSNP in Ethiopia and NREGS in India); children mostly assessed these to have helped their families through difficult periods, even though it could be hard work for children. For example, RAJESH (case 4, discussed below) described how despite the destruction of his family's crops, NREGS income earned by his household meant that they could still afford to buy rice; the following year, NREGS work meant they could afford 'good food', school materials and clothing, and college fees for Rajesh's elder sister who had to stop studying (Camfield and Vennam, 2012:28).

\section{Enabling systems and environments}

In addition to NGO support, children benefited from intersecting enabling systems and environments in their homes, schools and communities. In practical terms, an enabling home environment was food-secure, and one in which families relieved those young people who had progressed far in their education from burdensome paid and unpaid work so that they could spend more time studying and preparing for exams; foregone work was sometimes delegated to younger siblings or to outside help.

Flexible school systems and sympathetic teachers made a difference to children when they were unable to afford school-related costs or when they missed school due to personal or family illness and for seasonal work. Equally, children (who fared worse) cited inflexible school systems and personal conflicts with school teachers as a chief reason pushing them out of school.

Children valued community-level development that benefited their households and their future prospects. Many children noted the introduction of electricity into their 
communities and households since it meant they could study at night. They also mentioned changes improving livelihoods. For example, rural boys in Ethiopia identified the switch from rain-fed to irrigation agriculture as a major positive change improving farming outputs and increasing earnings. Such changes were a notable source of renewed hope for young men who might otherwise have considered migrating away to look for work. Urban development could also inspire hope when children could access the benefits (Crivello and van der Gaag, 2016).

Conversely, community shocks like floods, droughts and crop pests, deepened household vulnerability and threatened to derail children's aspirations. When La Roya coffee plague hit Maria and Elmer's region, families made changes; they planted different crops, worked on other people's farmland and migrated in search of work.

Social values that legitimated girls' and boy's school participation were supportive of children's positive trajectories, although the realities of poverty made it difficult to always live up to them. Over time, young people grew more aware of structural inequalities. Mulu (Ethiopia), for example, was intent on challenging gender stereotypes at school. She chose not to accept an invitation to join her school's girls-only tutor group for math, instead opting to study informally with her peers; she reasoned that targeting girls sent the wrong message about girls' competencies, since girls in her school outscored boys in math. Several of the girls who fared well resisted the female disadvantage they observed in their societies. Maria (Peru), echoing her mother, said living in a 'machista' society made it important for her to gain financial independence through a profession. Many of the girls who aspired to professional careers knew of young women either from their communities or 'like them' who were already working in their desired professions. Entrenched gender norms in childhood affected boys too, and many left school earlier than girls, reflecting stereotypes of the masculine breadwinner.

\section{Individual resources: the strengths that children bring}

Support for children who fared well did not exclusively come from external sources and systems. Children brought a diverse array of personal resources to bear when managing adversity. It was incumbent on many children to develop independence early on since many caregivers reported working long hours away from home. Urban mothers in Peru, for example, travelled long distances across the city to work in shops and as housemaids. Working mothers in Vietnam emphasised how their children needed to be responsible and independent. 
Children who fared well were self-motivated. They believed they could succeed, despite life's obstacles. They made plans, and had a positive outlook. They were proactive in accessing migration networks that connected them to opportunities for schooling and work and new aspirations. They managed their paid and unpaid work responsibilities alongside schooling. Crucially, children fared well when their relationships, wider structures and opportunities supported their positive dispositions and competencies. In short, high aspirations and an optimistic attitude were not enough on their own to make a difference.

If the influence of personal resources is understood along a continuum, Sarada (India) sits confidently on one end of the spectrum, so determined was she to take the lead in authoring her evolving life script, at times taking risks and challenging authority to do so. Having her own income reinforced her tenacity and strengthened her bargaining power to delay marriage and to continue studying. She exclaimed,

'I boldly decided to study as I have my own income. I felt why shouldn't I study when everyone else is studying... I will not agree if my parents insist that I get married. I will not budge... I want to live my life as a single woman.'

Other children had a talent for being receptive to the help and advice from others. Rajesh (India), for example, being the youngest, and only son, accepted his three elder sisters' decisions about his education, 'whatever they say, I will study... my sisters are taking care of me so that I may prosper... they are preparing me, they got me joined in the courses now.' Similarly, Quoc (Vietnam) was open to being rescued from a downward path by his uncle and teacher. Elmer (Peru) had cultivated a friendship with a classmate who got him a job at the petrol station, which meant he could study during the day. Thus, relating well to others, or sociability, enhances children's social capital (Bourdieu, 1986) and may also increase children's access to material resources (cf Tekola, 2009).

Children who fared well received external affirmation from family and teachers in the form of praise, blessings, recognition and rewards, and these bolstered children's sense of their achievements. MESIH (case 2, Ethiopia) enrolled in school two years late and for a long time felt 'behind'. Aged 14, he reported modest academic ambitions, hoping to finish school and 'have a good life.' Over the years, he began to realise that he was a good student, often ranking top of the class, which spurred him to raise his ambition. By age 16, he had devised a plan for finishing Grade 12, and by age 18, he was implementing his plan, having migrated to town to live with his sister for schooling. Likewise, aged 12, Sarada said, 'I like it a lot when I am praised for performing well at 
school'. When her teachers began to praise her, she 'became brave', 'bolder', 'fearless'. Indeed, many of the young people had gained reputations for being bright and somewhat exceptional.

These young people's achievements need to be understood in the context of wider generational change, since many of them were navigating schooling systems and aspirations that would have been out of reach to their parents and caregivers when they were their age. Their parents/caregivers often did not have the cultural and social capital (the 'know how' and the 'know who') to inform the practical steps needed for children to get ahead. Some children charted their life paths on unfamiliar territory which was both exciting and daunting; they often took the lead in exploring options, whether out of inclination or out of necessity. When met with a tipping point, they dealt with it. Lien (Vietnam) summoned her wits and perseverance to craft the letter to her vice-principal that eventually led to her being able to re-sit her high school entrance exam which she went on to pass. Sarada persuaded her teachers to intervene on her behalf to convince her parents to let her go to school instead of working in debt bondage. Mulu was instrumental in convincing her mother to let her move to town with her sister so that she could continue studying, despite the added work burden this created for her younger sister. Maria convinced her father to let her move to the city to study nursing, despite his reservations about the costs and distance involved. Elmer devised a daily schedule that allowed him to study in the day and work nights. In short, children who fared well were active, resourceful and creative in pursuing opportunities. However, their individual dispositions and actions made the most difference when they were supported by their social relationships, material resources and wider enabling environments.

\section{Second chances and serendipity}

Several children spoke of second chances that were particularly crucial during turning points, such as with parental death or exam failure, as in several of the cases described earlier. In India, Rajesh, spoke throughout his childhood of education as the route to success. Initially very ambitious, his aims dwindled from age 12 ('I want to be a doctor') to age 20 ('whichever job I get fastest, that one I will take...It depends on fate'). His family were very poor; an illness meant he changed school age 13; aged 17 he had a motorbike accident and his father fell ill; his family took on debts to pay for his sister's undergraduate degree. By age 19, he had moved to a nearby town for two months' training 
as a security guard, and then was sent to Chennai to work. However, after a year, he returned to the village - he had been working at night but was very homesick:

'[I]t was hard to do night duties, and moreover it is far away from our place, I felt

I have lost something in life, ... I wanted to come back.'

By age 20, he was living in his village, supporting his family, and had returned to education. His elder sisters (both teachers) made most of the decisions in the household, and they encouraged him throughout his childhood to study. By age 22, Rajesh spent most of his time attending college.

Second chances were not random, however, and children were not passive in responding to them. It was necessary that children had the inclination to take advantage of such opportunities, whether or not they were in the lead. In Vietnam, compulsory military service was a kind of second chance for some boys who had left school and whose prospects were limited:

For boys from disadvantaged families, military service in the army can present opportunities for social mobility and some parents, especially from rural areas, appear to value the life skills, such as self-discipline and communication skills, that the military service can teach their children. (Zharkevich et al, 2016)

Second chances then had the power to shift children's trajectories in differing ways. They helped children return to a 'pathway' they never wanted to leave in the first place, and they redirected and opened up new pathways offering a renewed sense of hope.

\section{Whose definition of success?}

A study of this kind begs the question: who defines 'success'? Whose conceptualisation of resilience matters? Most studies of resilience have focused on childhoods in highincome countries, and there is a tendency to apply standards of white middle-class childrearing and child competence to childhoods across the globe (Ogbu, 1981). The role of culture and context in definitions of resilience in children remains neglected (Ungar, 2008). One benefit of Young Lives design has been insights into the diversity of childhood and family experiences. Analysis prioritising children and young people's accounts deepened our understanding of what matters most to them, their perceptions of risk and protection and what fuelled or diminished their agency and hope. As children, they valued school-based education, material security, being respected and harmonious family lives. As youth, they have varied goals and differing paths towards achieving them. Many of them have shifted their focus from formal education; their concern is how 
their years of schooling will translate into decent work and, more generally, better lives. For young men, the prospect that underemployment will undermine their capacity to marry and support a family is troubling. For those who have become parents, their orientation is towards improving the wellbeing of their children and young families. We included Quoc (Vietnam) as a case study, because although he decided to leave school after failing his exam, he might be said to be leading a life he has 'reason to value' (Sen, 2000) reflecting his emerging sense of adult masculinity as a boyfriend, father and supporter of his ageing parents. Indeed, taking a step back from a strictly outcomesfocused reading of young people's trajectories illuminates with greater clarity the strengths and achievements of young people who continue to struggle to get ahead - the ones who would appear to be living up to the odds, rather than beating them.

Young Lives' focus on children's everyday experiences of poverty has meant appreciation for 'ordinary' childhoods and for a holistic understanding of child wellbeing. Take, for example, two of the boys, now young men. Mesih (case 2) and Hadush (not a core case) from the same village in Ethiopia; both their households were classified as among the poorest. Hadush (youngest of 8 siblings) only attended school for three days, age 7 , before leaving for good, since he was the only boy at home to do the herding. Likewise, Mesih (fourth of 5 siblings) was needed for herding so he joined school two years late, age 9. Hadush did not overcome his false start in school, whereas Mesih followed a slow start in school with steady progress. By age 19, both Mesih and Hadush were feeling positive about their futures. Mesih had stopped working when he moved to his sisters' in town to continue studying. Hadush's life was transformed, age 16, when his family acquired irrigated farmland, since before he 'was just sitting, doing no job.' He said he could now help himself and his family and wanted to learn new farming and business skills to improve his future. Although both boys were faring well, our selection process for this paper identified Mesih as a case of 'beating the odds'. Children like Mesih and Hadush do not fit easily into typologies. Indeed, young people articulated 'resilience' and 'vulnerability' in terms of being 'strong' or 'weak', definitions that focus less on specific outcomes and more on how children respond to their changing circumstances. Mulu, at age thirteen, described resilient people as 'strong', 'they find solutions to problems and that is how they become able to have a good life.' In these definitions, Hadush's trajectory might be seen as positive, a form of resistance even (Bracke, 2016; Neocleous, 2013), through - his achievements, strengths and actions, rather than simply a 'failure' in educational terms. 
Our findings resonate with Masten's (2001) challenge to conceptualising the 'magical' nature of resilience as an exceptional outcome for a minority of individuals, suggesting instead that:

Resilience does not come from rare and special qualities, but from the everyday magic of ordinary, normative human resources in the minds, brains and bodies of children, in their families and relationships, and in their communities (p235).

From this view, the strengths of children are not only found in the 'exceptional cases' or 'outliers' but also across a wider array of childhood struggles and achievements.

\section{Discussion}

Following the same families over fifteen years provided a valuable window into children's lives in changing contexts. Daily life for many children was a balancing act of poverty and tipping points stemming from illness, conflicts at home and school, and climatic shocks affecting livelihoods. Rarely did a life stressor occur in isolation; more often, they intersected, layered and accumulated. Scarcity of support in these circumstances compromised life chances and bright futures, dampening hope and aspiration. Those children who fared well under multiple pressures accessed individual resources that helped them confront life's challenges (Figure 3).

Figure 3: Factors supporting children's positive trajectories

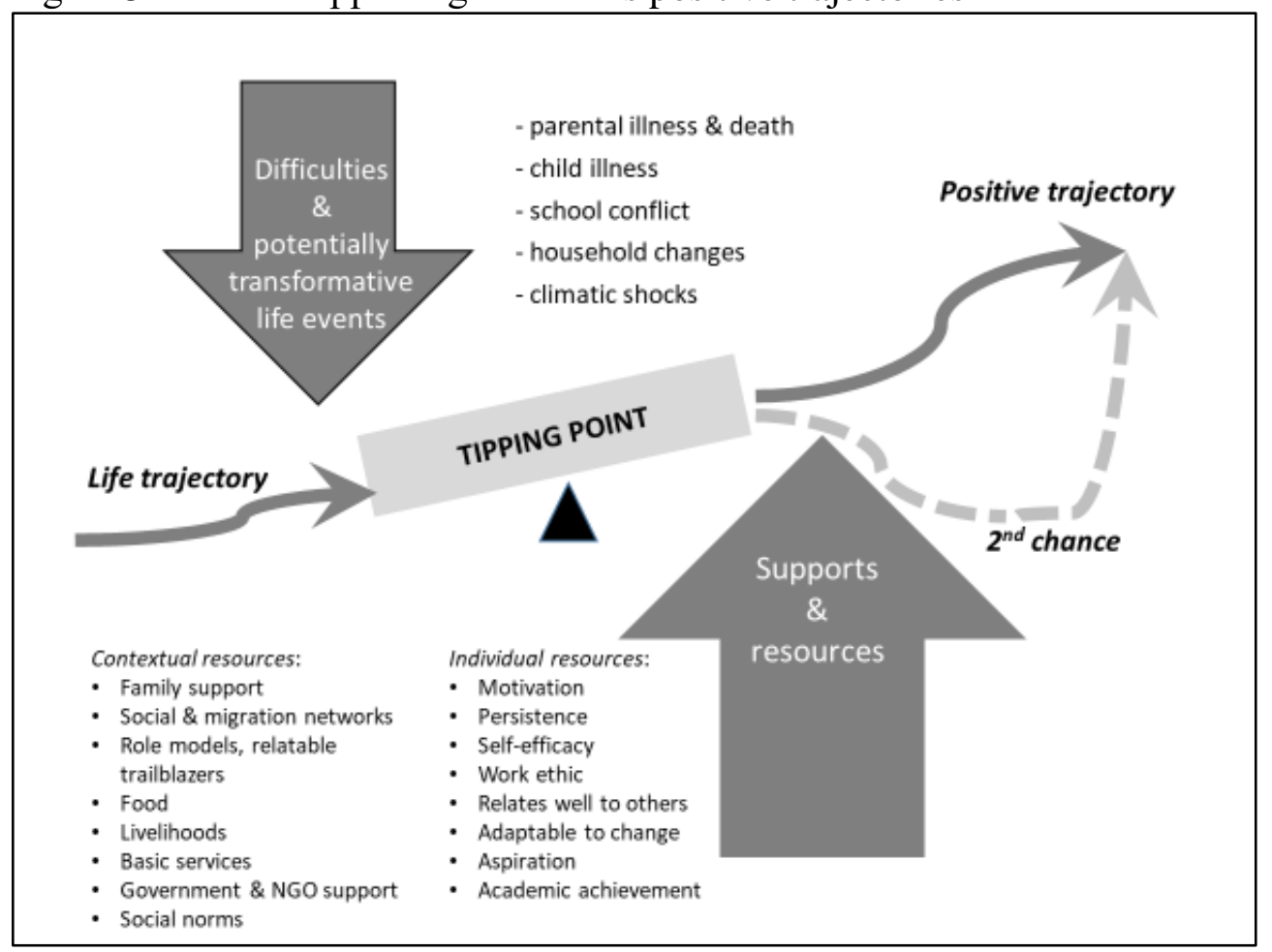


(Source: Life Course Timeline Exercise, Repeat Biographical Interviews, Round 5 Survey)

However, individual talent, motivation and intellect were not enough on their own. We therefore sound a note of caution about understandings and uses of the term 'resilience' that place responsibility on individual children to overcome vulnerability, suggesting instead attention to encouraging supportive systems and to second chances.

Supportive environments were necessary to catalyse and sustain positive trajectories. Children's reliance on the assistance, mediation, care and encouragement from their relatives and wider social networks was striking, as was the importance of short- and long-distance migration for rural children (cf Crivello, 2010; Juarez et al, 2013; Porter et al, 2010). Indeed, the fundamental importance of relationality and interdependence calls into question understandings of 'resilience' as a property of individuals (Bracke 2016: 73). Recall how Mulu's success was to some degree at the expense of her younger sister who remained at home taking on extra work responsibilities created by Mulu's departure to university. Sarada's younger siblings were debt-bonded and not attending school. Other children reported elder sisters delaying getting married, investing instead in younger siblings' schooling, as in the case of Rajesh's sisters ('they want to first develop me and then get married'). Moreover, faring-well entailed effective navigation of gender norms that pull girls and boys in particular directions, such as the feminisation of reproductive labour that locates girls' responsibilities within the home, and the social pressures on boys to comply with stereotypes of the male breadwinner that make it difficult for them to continue in school.

How then to recalibrate the tipping points towards more equitable conditions, reducing the difficulties and increasing the supports for children in poverty? By way of conclusion, we briefly highlight four policy implications reflecting the experiences and narratives of children in this study.

Firstly, poverty reduction is foremost. The aspects of poverty that most impacted the children we looked at appeared to be food insecurity, meeting school costs (e.g., hidden fees, transport) and the social and economic costs of ill-health within households. Broad-based, child-sensitive social protection is required to mitigate these costs for poor families so that children are not required to choose between working, caring, food or school. Secondly, schools need to be flexible and accommodating to the needs of children in poverty. This might include shift systems that allow working children to attend school 
and non-punitive approaches to school absences for caregiving and working children; as well as investments in teaching approaches that recognise and support the poorest children and that hold teachers accountable and reward them for helping children to catch up after absences. Thirdly, elder siblings and other young relatives were relatable trailblazers influencing the aspirations and life projects of those children in the study who fared well despite poverty. Children with weak social connections and role models were at a distinct disadvantage. Programmes, schools and media can reach children, families and communities, by promoting local examples with whom marginalised children and families can relate and learn from. Fourth, and more difficult to translate into policy terms, is the importance of second chances, and individuals facing multiple challenges sometimes needed third and fourth chances to avoid slipping. Children need second chances beyond school too. For example, many girls who married in adolescence wanted to continue studying, and those who had children wanted opportunities to gain skills for work, but they lacked social permission, opportunities and childcare. Children who left school after exam failure yearned for a second chance in the labour market, but good jobs were scarce. Keen to start their own small businesses, they were frequently excluded from loan programmes and training schemes on account of their age. Supporting work opportunities for young people in the majority world needs to broaden beyond formal job creation, and crucially, must address the prevailing feminisation of reproductive work that contributes to gender disparities in work and beyond.

Finally, our evidence cautions against snapshot approaches to gauging 'successful' transitions at any one age, for any one child, since the longitudinal approach shows that trajectories remain fragile. The role of serendipity is important. Policy approaches need to build on the strengths and high aspirations of children in poverty who work hard for their families and for themselves, understanding "how young people have negotiated their precarious circumstances and how these coping capacities can be harnessed in interventions" (Munford and Sanders 2019: 194). The policy spotlight on disadvantaged adolescents should focus less on individual risky behaviours, and instead shine more lucidly on strengthening the supportive systems around them in a way that not only helps individuals in beating the odds but also results in changing the odds for all. 


\section{Acknowledgements}

The authors thank the children and families who participate in Young Lives, for giving their time and for sharing details about their lives, and the researchers with whom we work. Thanks also to Bridget Azubuike, Grace Chang and Jennifer Roest for excellent research assistance, to Garth Stewart who designed Figure 2, and to Paul Dornan who was a consistent intellectual support in writing this paper. We are also grateful for the suggestions provided by anonymous reviewers.

\section{Disclosure statement}

The authors confirm no potential conflict of interest.

\section{Funding}

Young Lives is core-funded from 2001 to 2017 by UK aid from the Department for International Development (DFID).

\section{Notes}

1. Less developed regions include all regions of Africa, Asia (except Japan), Latin America and the Caribbean, Melanesia, Micronesia and Polynesia (UNFPA 2014).

2. www.younglives.org.uk In India, the study is conducted in Telangana and Andhra Pradesh states.

3. See https://www.younglives.org.uk/ The sample is pro-poor and not nationally representative, including similar numbers of girls and boys across a range of social groups in urban and rural contexts.

4. The variables were: gender, location, migration status, wealth index, current enrolment, highest grade achieved, current grade enrolled, reading and math scores, peer-relations, self-efficacy, self-esteem, pride, agency index, subjective wealth of household, marital status, economic activity, type of activity, payment, satisfaction with work.

5. The wealth index is a composite index reflecting service access, housing conditions and consumer durables and is calculated for each Young Lives household based on survey data.

6. Female and male enrolment rates: Ethiopia $65 \%$ v. $56.4 \%(\mathrm{n}=908)$; India $40.9 \% \mathrm{v}$ $56.6 \%(n=945)$; Peru 43.6\% v 41\% ( $n=631)$; Vietnam 53\% v 43\% $(n=860)$. See Round 4 factsheets www.younglives.org.uk 


\section{References}

Anderson, J. (2007). Urban Poverty Reborn: A Gender and Generational Analysis. Journal of Developing Societies, 23(1-2), 221-241.

Berlant, L. (2006). Cruel Optimism. Differences : A Journal of Feminist Cultural Studies, $17(3): 20-36$.

Blanden, J. (2006). 'Bucking the Trend': What Enables those who are Disadvantaged in Childhood to Succeed Later in Life? (Working Paper No. 31). Norwich: Department for Work and Pensions.

Boyden, J., Dawes, A., Dornan, P. \& Tredoux, C. (2019) Tracing the Consequences of Child Poverty: Evidence from the Young Lives Study in Ethiopia, India, Peru and Vietnam. Bristol: Policy Press.

Boyden, J. (2013). 'We're Not Going to Suffer like this in the Mud': Educational Aspirations, Social Mobility and Independent Child Migration among Populations Living in Poverty. Compare, 43(5): 580-600.

Boyden, J. \& Cooper, E. (2007). Questioning the Power of Resilience: Are Children up to the Task of Disrupting the Transmission of Poverty? (Working Paper No. 73). Manchester: CPRC.

Boyden, J. \& Mann, G. (2005). Children's Risk, Resilience, and Coping in Extreme Situations. In M. Ungar (Ed.), Handbook of Working with Children and Youth : Pathways to Resilience across Cultures and Contexts (pp. 3-26). Thousand Oaks, CA: Sage.

Bourdieu, P. (1986). The Forms of Capital. In J. Richardson (Ed.) Handbook of Theory and Research for the Sociology of Education (pp. 241-258). New York: Greenwood.

Bracke, S. (2016). Bouncing Back : Vulnerability and Resistance in Times of Resilience. In J. Butler, Z. Gambetti \& L. Sabsay (Eds.) Vulnerability in Resistance (52-75). Durham: Duke University Press.

Bronfenbrenner, U. (1979). The Ecology of Human Development. Cambridge, Mass: Harvard University Press.

Camfield, L. (2012). Resilience and Well-being among Urban Ethiopian Children: What Role do Social Resources and Competencies Play?. Social Indicators Research, 107: 393-410.

Camfield, L. \& Vennam, U. (2012). From Policy to Implementation: An In-depth Exploration of the Mahatma Gandhi National Rural Employment Guarantee 
Scheme in Andhra Pradesh (Working Paper No. 82). Oxford: Young Lives.

Cooper, E. \& Pratten, D. (2015). Ethnographies of Uncertainty in Africa. Basingstoke: Palgrave Macmillan.

Crivello, G. (2015). 'There's No Future Here': The Time and Place of Children's Migration Aspirations in Peru. Geoforum, 62: 38-46.

Crivello, G. (2010). 'Becoming Somebody': Youth Transitions through Education and Migration in Peru. Journal of Youth Studies, 14(4): 395-411.

Crivello, G. \& van der Gaag, N. (2016). Between Hope and a Hard Place: Boys and Young men Negotiating Gender, Poverty and Social Worth in Ethiopia (Working Paper No. 160). Oxford: Young Lives.

Crivello, G., Morrow, V. \& Wilson, E. (2013). Young Lives Longitudinal Qualitative Research: A Guide for Researchers (Technical Note No. 26). Oxford: Young Lives.

Simone Datzberger, S. (2018). Why Education is not Helping the Poor: Findings from Uganda. World Development, 110: 124-139.

Dornan, P. \& Woodhead, M. (2015). How Inequalities Develop through Childhood: Life Course Evidence from the Young Lives Cohort Study (Discussion Paper No. 2015-01). Florence: UNICEF Office of Research.

Gilligan, R. (2015, November). 'Comments as Respondent at Launch of the Research Report The Educational Progress of Looked After Children in England: Linking Care and Educational Data', London: Nuffield Foundation.

Gough, K.V. \& Langevang, T. (Eds) (2016). Young Entrepreneurs in Sub-Saharan Africa, London and New York: Routledge.

Jeffrey, C., Jeffery, P. \& Jeffery, R. (2008). Degrees without Freedom? Education, Masculinities and Unemployment in North India, Stanford, CA: Stanford University Press.

Jeffrey, C. (2010). Geographies of Children and Youth I: Eroding Life Maps. Progress in Human Geography, 34(4): 496-505.

Jeffrey, C. \& Dyson, J. (2008). Telling Young Lives, Philadelphia: Temple University Press.

Jeffrey, C. \& McDowell, L. (2004). Youth in a Comparative Perspective: Global Change, Local Lives. Youth and Society, 36: 131-142.

Johnson-Hanks, J. (2002). On the Limits of the Life Cycle in Ethnography: Toward a Theory of Vital Conjunctures. American Anthropologist, 104(3): 865-80. 
Jones, G.A. \& Chant, S. (2009). Globalising Initiatives for Gender Equality and Poverty Reduction: Exploring 'Failure' with Reference to Education and Work among Urban Youth in The Gambia and Ghana. Geoforum, 40(2): 184-196.

Juárez, F. \& Gayet, C. (2014). Transitions to Adulthood in Developing Countries. Annual Review of Sociology, 40: 521-538.

Juárez, F., LeGrand, T., Lloyd, C., Singh, S. \& Hertrich, V. (2013). Introduction: Youth Migration and Transitions to Adulthood in Developing Countries. Annals of the American Academy of Political and Social Science, 648: 6-15.

Langevang, T. (2008). 'We are Managing!' Uncertain Paths to Respectable Adulthoods in Accra, Ghana. Geoforum, 39: 2039-47.

Lerner. R.M. (2008). The Good Teen. New York: Random House.

Lippman, L. H., Anderson Moore, K. \& McIntosh, H. (2009). Positive Indicators of Child Well-being: A Conceptual Framework, Measures and Methodological Issues (Working Paper No. 2009-21). Florence: UNICEF Office of Research.

Locke, C. \& P. Lloyd-Sherlock, P. (2011). Qualitative Life Course Methodologies: Critical Reflections from Development Studies. Development and Change, 42: 1131-1152.

MacLeod, J. (2009). Ain't No Makin' It: Aspirations and Attainment in a Low-income Neighborhood. Boulder, CO: Westview Press.

Masten, A.S. (2001). Ordinary Magic: Resilience Processes in Development. American Psychologist, 56(3): 227-238.

Masten, A.S., Burt, K.B., Roisman, G.I., Obradović, J., Long, J., \& Tellegen, A. (2004). Resources and Resilience in the Transition to Adulthood: Continuity and Change. Development and Psychopathology, 16: 1071-1094.

Morrow, V. (2013). Troubling Transitions? Young People's Experiences of Growing Up in Poverty in Rural Andhra Pradesh, India. Journal of Youth Studies, 16(1): 86100.

Munford, R. \& Sanders, J. (2019). Harm, Opportunity, Optimism : Young People's Negotiation of Precarious Circumstances. International Social Work, 62(1): 185197.

Neocleous, M. (2013). Resisting Resilience. Radical Philosophy, 178: 1-7.

Ogbu, J.U. (1981). Origins of Human Competence: A Cultural-Ecological Perspective. Child Development, 52(2): 413-429. 
Pells, K. \& Morrow, V. (2018). Children's Experiences of Violence: Evidence from the Young Lives Study in Ethiopia, India, Peru and Vietnam (Summative Report). Oxford: Young Lives.

Perlman, J. (2010). Favela: Four Decades of Living on the Edge in Rio de Janeiro. Oxford: Oxford University Press.

Pilling, D. (1990). Escape from Disadvantage. Falmer Press, London.

Porter, G., Hampshire, K., Abane, A., Robson, E., Munthali, A., Mashiri, M. \& Tanle, A. (2010). Moving Young Lives: Mobility, Immobility and Inter-Generational Tensions in Urban Africa. Geoforum, 41(5): 796-804.

Ragin, C. \& Becker, H.S. (1992). What is a Case? Exploring the Foundations of Social Inquiry. Cambridge: Cambridge University Press.

Rutter, M. (1990). Psychosocial Resilience and Protective Mechanisms. In J. Rolf, A.S. Masten, D. Cicchetti, K.H. Nuechterlein \& S. Weintraub (Eds.), Risk and Protective Factors in the Development of Psychopathology (pp. 181-214). Cambridge: New York.

Ryff, C. D. \& Singer, B. (2003). Flourishing under Fire: Resilience as a Prototype of Challenged Thriving. In C. L. M. Keyes \& J. Haidt (Eds.), Flourishing: Positive Psychology and the Life Well-lived (pp. 15-36). Washington, DC: American Psychological Association.

Scheper-Hughes, N. (2008). A Talent for Life: Reflections on Human Vulnerability and Resilience. Ethnos, 73(10): 25-56.

Sen, A. (2000). Development as Freedom. New York: Anchor Books.

Smith, B.W., Dalen, J., Wiggins, K., Tooley, E., Christopher, P. \& Bernard, J. (2008). The Brief Resilience Scale: Assessing the Ability to Bounce Back. International 
Journal of Behavioral Medicine, 15: 194-200.

Tafere, Y. (2014). Education Aspirations and Barriers to Achievement for Young People in Ethiopia (Working Paper No. 120). Oxford: Young Lives.

Tekola, B.G. (2009). Looking Beyond Poverty: Poor Children's Perspectives and Experiences of Risk, Coping and Resilience in Addis Ababa (Doctoral dissertation). Department of Psychology, University of Bath.

UNFPA (2014). The Power of 1.8 Billion Adolescents, Youth and the Transformation of the Future. UNFPA State of the World Population 2014. New York: UNFPA.

Ungar, M. (2011). The Social Ecology of Resilience: Addressing Contextual and Cultural Ambiguity of a Nascent Construct. American Journal of Orthopsychiatry, 81(10): $1-17$.

Ungar, M. (2008). Resilience across Cultures. British Journal of Social Work, 38(2): 218235.

Ungar, M. (2004). A Constructionist Discourse on Resilience: Multiple Contexts, Multiple Realities among At-Risk Children and Youth. Youth \& Society, 35(3): 341-365.

Ursin M. \& Abebe, T. (2017). Young People's Marginal Livelihoods and Social Transitions in Urban Brazil: Tale of Four Lives. In T. Skelton, T. Abebe, \& J. Waters (Eds.) Laboring and Learning. Geographies of Children and Young People, vol 10. Singapore: Springer.

Vigh, H. (2006). Navigating Terrains of War: Youth and Soldiering in Guinea-Bissau. New York: Berghahn Books.

Werner, E. \& Smith, R. (1982). Overcoming the Odds: High Risk Children from Birth to Adulthood, Ithaca: Cornell University Press.

White, B. (2011, October). Who Will Own the Countryside? Dispossession, Rural Youth and the Future of Farming, Valedictory Lecture, The Hague: International Institute of Social Studies.

Zharkevich, I, Roest, J. \& Vu, H.T.T (2016). Gendered Trajectories through School, Work and Marriage in Vietnam. (Working Paper No. 158) Oxford: Young Lives. 